3rd. The Staff Surgeon.-Of this class of officers (who must necessarily have served a very long time as surgeon and assis tant-surgeon, and who, owing to the impossibility of constant employment in the navy, must be men of advanced age) a few are still serving in our sea-going ships, and $\mathbf{a}$ few in the harbour and coast guard ships. Afioat, they are treated exactly as the surgeon, have a cubin in the cockjit, a second-class boy as a servant, dependent on the commanding offeer's will and plea sure, and share prize money with the curpenter. Though of a distinct and elevated rank, well earned by long service, they are denied a separate place in the Navy List-unlike their brother officers, the surgeons-major, in the Army List; and though their denomination would lead to the supposition that, as a matter of course, they would only hold staff appointments or be allowed to go on half pay, they are denied the one, and have the mortification to see their juniors hold the other-men with good interest, though little service.

4th. Deputy Inspectors and Inspectors-Genercl.-These aro high-sounding titles, ranks never arrived at except by a favoured few, who fill up the hospitals, dock yards, and other staff appointments until an opportunity offers for their further advancement; bat even these oficers are not allowed to take their proper position, and proportionably suffer as their juniors in other respects.

I might continue at much greater length, but fear $I$ have already trespassed too much on your valuable space; but your readers will readily see that we in the navy are worse treated than our brethren in the army. One order in the Naval Warrant has been contemptuously disobeyed altogether. I allude to the good service pensions, which have been granted, though to a very limited extent, in the army. I cans.ot, on the part of our body generally, too strougly disavow foolish absurdities perpetrated by a few surgeons, in not only demanding the precedence which was their due, bnis also military power, which they had no claim to; bat we do ask for the redress of the grievances to which I have allarled. This I state with confidence that very many of us would prefer to be, as chaplains, without any military rank, (as our profession, hike theirs, carries its own precedence,) wear plain clothes, and take our stand alone on our University degrees.

September, 1861 . I am, Sir, respectfully yours, A N'Aval Surgeor.

\section{MOTION AND REST IN THE TREATMENT OF SURGICAL AFFECTIONS. To the Ealitor of The LaNCET.}

Sre, - In a work published by Justamond, Surgeon to the West. minster Hospital in 1730 entitled "On Hotion and Rest in the Treatment of Surgical Diseases and Injuries," the autbor has cited numerous cases very similar to those published by Mr. Hilton, although I do not think any are exactly parallel. Mr. Hilton, although he appears never to have tried it, will find that he can best fix a joint motivnless by encasing the whole or a portion of it in a plaster-of-Paris cast. I think that motion, as well as rest, is exceedingly important in the treatment of surgical affections, and I trust the medical public may not be led too much into the do.nothing system, to which many men an large pructices are much tempted.

$$
\text { I am, Sir, yours very truly, }
$$

King's Lynn, Norfolk, Sept, 1861 .

$$
\text { G. B. SWEETING, M.R. C.P. Lond. }
$$

\section{MEDICAL DESTITUTION AND TRUTH IN GLASGOW. \\ To the Editor of The YANCET.}

SrR,-Being a member of the Faculty of Medicine in Glasgow, and having been at the meeting when the question was taken up regardinir consulting practice, and being chosen at that meeting as one of a committee to examine and consiler the sulject, I was somewhat startled to see in THE LANCET of the $7 \mathrm{~h}$ h inst. the following statement made by Dr. $M^{\circ} \mathrm{Carron}$ :

"From cuses whith came under" my own observation, showed that this fear was not altogether groundless; I showed that he whom we brought in as consulting surgeon might now and then be found taking our place as family attendant; but in so doing I made no allusion, 'pointerl' or otherwise, to any particular person in the protession. I only stated general facts. If personal allusions were made, I cannot charge myself with them ; to some of the gentlemen who followed me must they be credited."
To say nothing of the incongruity of this gem of composition there must be some very egresions mistake, or it must be a shameful and cowardly nisst. tement; for the truth is that the question was brought under the no ice of the Faculty by Dr. W'Carron, and, whilst stating the unsatisfactory state of consulting practice in Glasgow, he distinctly mentioned a caso which occurred with him and Dr. Bell.* Upon due inquiry and consideration by the Faculty, it was found that Dr. Bell had done nothing contrary to the etiquette of the profession and was one of the few who in consultation has al ways acted an honourable part. Dr. M'Carron was compelled, as well as others, to give bonâficle cases, otherwise the Facnlty would not enter upon the consileration of the question. Hence several cases were given by various gentlemen, when it appeared that buth the consulting practice and medical etiquette in get eral were so flagrant and so dastard that they cannot bear the light of your pages, - a state of things which some of the commirtee thought arose from the fact, that a number of men in the profession assumed a posicion for which they had neither the means nor ability, heuce they were compelled to adopt every low artifice to keep their heark above water.

I am, Sir, yours, \&c.

Great Hamilton-street, Glasgow, Sept. 1861. JAS, GLASS, T.F.P.S.

\section{ABSENCE OF SYMPTOMS IN EXTENSIVE DISEASE.}

To the Editor of THe LANCET.

SrR,-I think the following case remarkable from the fact that, although after death so extreme an amount of structural change was discorered, any symptoms which might lead one to suppose such a state of things during life were perfectly absent, and comparative good health enjoyed by the patient, although the diseased structure subsequently discovered must have existed from birth.

A boy nine years old died after a week's illness with symptoms of acnte peritonitis and extensive effusion into the peritoneum. With the exception of being tronbled once with ascarides, the mother stated that her boy always enjoyed good health, and was remarkably active and cheerful for his age. On examination after death, besides the usual marks of universal peritonitis, an enormous mass of tubercular matter was found connected with the mesentery, and had it been possible to disengage it thoroughly from its numerous attachments and obtain it separately, ic must have amonnted to several pounds in weight. The principal mass, completely encircling the large intestine, and consilerably diminishing its calibre, was nearly as large as the chili's head. Another point was re. markable-namely, the entire absence of tubercle from every other organ; lungs, liver, spleen, and kidneys were perfectly healthy. I am, Sir, your obedient servant,

Stoke Newington Dispensary, Sept. 1861. Charles Ross.

\section{PARISIAN MEDICAL INTELIIGENCE.}

\section{(FROM OUR SPECIAL CORRESPONDENT.)}

IN a recent communication to the Academy of Sciences, M. Guyon calls the attention of the profession to a condition already observed in some of the aggravated forms of yellow fever-namely, the suspension of the heart's action, absence of radial pulse, and death-like chill of the cutaneous surface, coexisting with perfect integrity of the intellectual faculties. "English physicians," says the au hor of this essay, " designate this particular variety of yellow fever as the algid form, and the Spanish writers refer to it as the 'frio-marmoreo,' or marble-cold type." The special case which forms the subject of M. Guyon's dissertation, is that of a sailor, of robust con. stitution, who, bringing from Africa the germ of yellow fever, became a patient in the Naval Hospital at Lisbon. When examined by M. Guyon, he was lying on his back, cold and motionless, without pulse, and without any apparent action either of the heart or lungs; his eyes were open, but fixed, and seemingly as incapable of movement as the rest of the body. This condition had persisted since the preceding evening, and

* I give ne name of the talented gentleman, because it has been whispered in a sinister way all over the city. 